\title{
Public Conflicts, Democracy and Authoritarianism
}

Lessons of History

Alexey S. Avtonomnov

Conflicts between branches of government reflect growing conflicts within the public domain regardless of what political regime is at the helm. Society in general develops through conflicts arising from objective causes. A conflict within society is an objective phenomenon and therefore is inevitable. At the same time, conflicts take less time to mature and are more distinct in a democracy than in an autocracy, and thus, conflict management is normally more effective in a democratic setting.

While speculating on whether Donald Trump and Theresa May are hostages to their respective parliaments, José Ignacio Torreblanca, head of the Madrid Office of the European Council on Foreign Relations, has remarked that conflicts between branches of government exist in democracies because they are inherent in their nature and mode of functioning. On the other hand, these conflicts, he claims, are basically impossible in authoritarian states like Russia, China or North Korea. I think this is an unjustified simplification.

Alexey S. Avtonomnov is a Member of the UN Committee on the Elimination of Racial Discrimination; Professor, Vice-Chancellor of the Griboyedov Institute of International Law and Economics. Originally published by the International Valdai Discussion Club at: http:// valdaiclub.com/a/highlights/public-conflicts-democracy-and-authoritarianism/

DOI: $10.31278 / 1810-6374-2019-17-2-35-40$ 
Indeed, there have been no conflicts in Russia between the Duma and the president over the last 20 years, but conflicts were frequent in the 1990s. For example, the Duma never approved the law on displaced cultural valuables that the president was promoting, and it overrode the presidential veto. This is to say that the relevant powers do exist, although at that time they were hardly used. However, this is a different matter that has more to do with political practice than authority per se. The Duma can reject a bill and there are constitutional mechanisms for overriding a presidential veto. There have been examples of this, and it is hard to say that they are unheard of.

In Russia, the parliamentary majority is held by the party that supports the president. A similar situation is common in many countries, where the dominant party supports the president. In the United States, a bill can be approved in Congress very quickly if the majority in both houses is controlled by the president's party.

Likewise, the Russian Constitution has a clause on impeachment and there were several attempts in the 1990s to put that mechanism into motion. But like everywhere else, this procedure is highly complicated, requiring a qualified majority vote in the Duma (presentation of charges), Supreme Court and Constitutional Court rulings, and a final decision by the Federation Council. And this is logical. If a parliamentary majority party is in opposition to the incumbent president, attempts to impeach him can be expected in any country. How justified these attempts are is another matter. Politicians do not always provide motives for their actions, so laws in most countries contain a requirement that the filing of such serious charges must be well-founded and justified.

But it cannot be said that an impeachment is something unthinkable. In Russia, the parliamentary majority is held by the party that supports both the president and the government. Under these circumstances, no country would have impeachment attempts or other scandals.

At the same time, a stable democracy certainly needs independent courts. And this is the biggest problem. As I see it, courts, particularly low-level courts, often pervert justice, for 
which reason we have so many disagreements with the ECHR. Where housing and services payments are concerned (I can cite cases), justice courts and district courts disregard both the law and resolutions of the Supreme Court Plenum lincluding Resolution No. 22 of June 27, 2017, specifically dedicated to housing and services payments) and pass judgments favoring management companies without getting to the heart of the matter. But this is a different problem that is related to rule-oflaw rather than politics.

Now let's consider the idea that democracies rarely go to war with each other. I will dwell on this in order to draw a clear line between international relations and the state of affairs at home. The article in question refers to some unspecified empirical data. But empirical data do not corroborate the author's point. Greek poleis waged war against each other regardless of whether they were democracies, oligarchies or something else. The Roman Republic fought against other republics in Italy and outside of Italy. The best-known cases are the three bloody Punic wars between two republics, Rome and Carthage. The strengthening of basically democratic estate representative bodies (e.g. Estates General in France and Parliament in England) did not have a peacemaking effect on hostilities during the Hundred Years' War. Finally, during WWI, two democracies, France and Britain, were opposed by Germany that had a powerful parliament, whose lower chamber was elected by universal ballot and the monarch (King of Prussia), who in fact held the office of Federal President lunder its 1871 Constitution, Germany was a federated state) had no right even to a suspensive veto with regard to laws passed by Parliament. Germany's advanced legislation, multiparty system, and strong independent courts were also evidence that Germany was no less democratic than its WWI foes, Britain and France.

Some other examples are the 1846-1848 war between the United States and Mexico, the Anglo-American War of 1812, and subsequently, America's willingness to fight a new war with Britain and Canada, a British dominion until the early 20th century, as is evidenced by the costly construction of Fort Henry at Kingston, Canada, on the border with the United States 
(Britain used the latest in fortification techniques and materials). The Indian-Pakistani confrontation has continued for over 60 years, culminating in periodic armed clashes. India is a longtime democracy. Pakistan is a scene of military coups from time to time, leading to the establishment of an authoritarian regime, but there are periods of democratic rule as well. But the confrontation between the two countries has never let up, including when democratic regimes were in power on both sides of the border.

But let's go back to the domestic conditions that enable the functioning of a democracy. It should be noted that conflicts between branches of government reflect growing conflicts within the public domain regardless of what political regime is at the helm. Society in general develops through conflicts arising from objective causes. A conflict within society is an objective phenomenon and therefore is inevitable. At the same time, conflicts take less time to mature and are more distinct in a democracy than in an autocracy, and thus, conflict management is normally more effective in a democratic setting.

A democracy's stability derives from its ability to control conflict. Under authoritarian rule, however, conflicts are swept under the rug. But conflicts persist, albeit more discreetly. They intensify, expand and become more complex, with new conflicts cropping up in parallel, which end up being swept under the rug as well. In other words, tension grows while power resources are used to remove the outer signs of this tension from view. Sooner or later pent-up tension will lead to a social explosion and it is much more difficult to deal with it on this scale than to control incipient conflicts at an early stage. If tension is serious enough, any outside challenge to the state is able to provoke a crippling social explosion that results from the lack of internal unity, aggravation of antagonisms, and unresolved conflicts.

It is said that decision-making in the public domain under authoritarianism is effective because it takes little time. But the criterion of efficiency is whether decisions can solve a problem rather than how fast they are approved. If a rapid decision does not work and has to be improved, altered, abridged, or expanded, there is no question of efficiency. In most cases it leads to a clash 
of interests and ends up sabotaged, failing to achieve its goal. Under a democracy, decision-making can take longer but the outcome is a compromise between various agencies and other government bodies, political forces and public institutions. It takes into account different interests and approaches to problems and does not need to be expedited immediately after approval.

But democracy requires certain social conditions. In traditional tribal society, leadership is based on age, familial origin and kinship and it is accepted as natural and legitimate. Even if tribesmen are given the right to vote, they make a point of voting for their traditional leaders, as is evident from the records of a number of African and Asian countries. For reasons of social inertia, political culture is preserved even by people who leave their tribe and move to cities. No wonder, therefore, that in the heyday of democracy, the citizens of Athens did not regard elections as a democratic vacancy filling method. Lots were cast to fill all positions in the polis, except those of the strategists, because a man without relevant experience was not eligible to command the armed forces.

In addition, a democracy is stable when most people land ideally the entire population) are personally and economically independent. As for human bondage, serfdom and slavery are banned everywhere, and if they still exist, they do so illegally. As shown by history, economic independence is determined either by access to public (communal) landed property (Athens, Rome, Novgorod and Pskov in the Middle Ages), or dispersed private ownership by means of production, or an opportunity to receive an income independently as enjoyed by a large number of people (such as members of free professions). In Rome, for example, the growing prevalence of private ownership over public (state) ownership and the concentration of property in the hands of a relatively narrow circle of individuals led to a crisis of democracy and replacement of the republican system with an empire. Although the majority of republican institutions were preserved, the popular assemblies-the comitia-were convened less and less often. The last time they were called was under Emperor Nerva (96-98 AD), years after their previous convocation under 
Emperor Tiberius (14-37 AD). The emperor was still elected by the Senate, but the vote was a formal procedure and it was not the Senate that decided who would be emperor.

Finally, a democracy is stable if it is based on a widespread civic culture. Alert citizens are actively involved in public and government life because they regard involvement as a value and understand that it requires relevant knowledge. This is why they take an interest in politics and take a pro-active attitude to life. Citizens of a Greek polis, who took no interest in public and state affairs and who concentrated on their own private problems, were called idiots lat that time the word "idiot" lacked its present negative connotation). When the proportion of idiots increased beyond measure, democracy was ripe for crisis and decline.

Examples from history seem to reflect the universality of the laws of democracy in time and space. 